\title{
Down-regulation of Sp1 suppresses cell proliferation, clonogenicity and the expressions of stem cell markers in nasopharyngeal carcinoma
}

Jing-Ping Zhang ${ }^{1,2+}$, Hua Zhang ${ }^{1,2+}$, Hong-Bo Wang ${ }^{1,2+}$, Yan-Xian Li ${ }^{1,2}$, Gui-Hong Liu ${ }^{3}$, Shan Xing ${ }^{1,2}$, Man-Zhi Li $i^{1,2}$ and Mu-Sheng Zeng ${ }^{1,2^{*}}$

\begin{abstract}
Background: Transcription factor Sp1 is multifaceted, with the ability to function as an oncogene or a tumor suppressor, depending on the cellular context. We previously reported that Sp1 is required for the transcriptional activation of the key oncogenes in nasopharyngeal carcinoma (NPC), including B-lymphoma mouse Moloney leukemia virus insertion region 1 (Bmi1) and centromere protein $\mathrm{H}(\mathrm{CENPH})$, but the role of Sp1 and its underlying mechanisms in NPC remained largely unexplored. The objective of this study was to investigate the cellular function of Sp1 and to verify the clinical significance of Sp1 as a potential therapeutic target in NPC.

Methods: The levels of Sp1 in the normal primary nasopharyngeal epithelial cells (NPECs) and NPC cell lines were analyzed by Quantitative Real-time RT-PCR (qRT-PCR) and Western blot. The location and expression of Sp1 in the NPC tissues were detected by immunohistochemistry staining (IHC). The effect of Sp1 knockdown on the cell proliferation, clonogenicity, anchorage-independent growth and the stem-cell like phenotype in NPC cells were evaluated by MTT, flow cytometry, clonogenicity analysis and sphere formation assay.

Results: The mRNA and protein levels of Sp1 were elevated in NPC cell lines than in the normal primary NPECs. Higher expression of Sp1 was found in NPC tissues with advanced clinical stage $(P=0.00036)$. Either inhibition of Sp1 activity by mithramycin A, the FDA-approved chemotherapeutic anticancer drug or Sp1 silencing by two distinct siRNA against Sp1 suppressed the growth of NPC cells. Mechanism analysis revealed that Sp1 silencing may suppress cell proliferation, clonogenicity, anchorage-independent growth and the stem-cell like phenotype through inducing the expression of p27 and p21, and impairing the expressions of the critical stem cell transcription factors (SCTFs), including Bmi1, c-Myc and KLF4 in NPC cells.
\end{abstract}

Conclusions: Sp1 was enriched in advanced NPC tissues and silencing of Sp1 significantly inhibited cell proliferation, clonogenicity, anchorage-independent growth and the stem-cell like phenotype of NPC cells, suggesting Sp1 may serve as an appealing drug target for NPC.

Keywords: Nasopharyngeal carcinoma, Sp1, Cell cycle, Cell proliferation, Clonogenicity, Stem cell

\footnotetext{
* Correspondence: zengmsh@mail.sysu.edu.cn

${ }^{\dagger}$ Equal contributors

${ }^{1}$ State Key Laboratory of Oncology in South China, Sun Yat-sen University

Cancer Center, 651 Dongfeng Road East, Guangzhou 510060, China

${ }^{2}$ Department of Experimental Research, Sun Yat-sen University Cancer Center,

Guangzhou, China

Full list of author information is available at the end of the article
} 


\section{Background}

Nasopharyngeal carcinoma (NPC) is one of the leading malignancies in southern China and Southeast Asia $[1,2]$. The annual incidence rate reaches 30 cases per 100,000 people in the endemic regions, which is about 25-fold higher than in the rest of the world [1-3]. NPC shows familial clustering, resulting predominantly from inherited susceptibility [4]. Elevated levels of serum Epstein-Barr virus (EBV)-related antibodies, circulating and intratumoral EBV DNA were consistently detected in NPC individuals, demonstrating that EBV infection is a strong risk factor for NPC [5-7]. In addition, smoking and consumption of saltpreserved foods have also been reported to be the moderate risk factors for NPC $[8,9]$. Therefore, NPC is a malignancy with a complex etiology involving both genetic and environmental factors [1-3]. Although radiotherapy or chemo-radiotherapy has been acknowledged as standard treatment options, these treatments induce a considerable incidence of acute mucosal and hematologic toxicity [10-12]. Thus, it is urgent to identify the potential therapeutic agents for NPC.

Sp1 was identified as a transcription factor by binding to the promoters of its target genes and has been postulated to play important roles in the regulation of multiple critical biological functions, including cell apoptosis [13] and growth [14], cycle progression [15], purine/pyrimidine synthesis [16], metabolism [17], angiogenesis [18,19] and metastasis [20,21]. Growing evidence demonstrated Sp1 is abnormally expressed in a variety of epithelial tumors originating from different tissues, including breast [22], thyroid [23], pancreas [24], stomach [25] and lung [26]. Deregulation of Sp1 may promote tumor development through regulating transcription of genes, such as c-Myc [27], cyclin D1 [28], VEGF [29] and MMP9 [30]. In contrast, overexpression of $\mathrm{Sp} 1$ in highly invasive lung adenocarcinoma cells increases expression of E-cadherin and inhibits metastasis [20]. Moreover, Sp1 induces apoptosis through cooperating with p53 [31]. Therefore, Sp1 may serve as an oncogene or a tumor suppressor in tumor development and deserved to be studied in depth.

We previously identified $\mathrm{Sp} 1$ as an important transcription factor for oncogenes in NPC, including Blymphoma mouse Moloney leukemia virus insertion region 1 (Bmi1) and centromere protein $\mathrm{H}(\mathrm{CENPH})$, but the role of Sp1 in the development of NPC remains obscure $[32,33]$. In the present study, we found the level of Sp1 was elevated in advanced NPC tissues and silencing of Sp1 significantly inhibited cell proliferation, clonogenicity, anchorage-independent growth and the stemcell like phenotype of NPC cells, suggesting Sp1 as a potential therapeutic target for NPC.

\section{Materials and methods Reagents}

The reagents used were as follows: rabbit polyclonal antibodies against Sp1 (\#07-645, Millipore, Temecula, CA, USA), p27 (\#60-645, Millipore), CDK4 (ab137818, Abcam, Cambridge, MA, USA); mouse monoclonal antibodies (mAb) against p21 (sc-6246, Santa Cruz, CA, USA), $\alpha$-tublin (T6199, Sigma-Aldrich, St Louis, MO, USA), GAPDH (sc-32233, Santa Cruz). All other reagents were obtained from Sigma-Aldrich, unless otherwise indicated.

\section{Patients and tissue specimens}

The paraffin-embedded NPC specimens $(n=76)$ were obtained from Cancer Center of Sun Yat-sen University in Guangzhou, People's Republic of China. Written informed consent was obtained from each patient, and the study was approved by the Institute Research Ethics Committee at the Cancer Center. The clinical characteristics of the NPC patients were described in Table 1. All cases were histologically confirmed.

\section{Cell culture}

Normal primary NPECs (NPECw and NPEC01) were established as described previously [34], and cultured in keratinocyte/serum-free medium (Invitrogen, Carlsbad, CA, USA). The NPC cell lines (CNE2, HNE1, HONE1, C666-1 and HK1) were cultured in RPMI 1640 (Invitrogen, Carlsbad, CA) supplemented with $10 \%$ fetal bovine serum (FBS; Hyclone, Logan, UT), and in a humidified $5 \% \mathrm{CO} 2$ incubator at $37^{\circ} \mathrm{C}$.

\section{SiNRA transfection}

The siRNA oligoribonucleotides were purchased from Dharmacon (Rockford, USA) and Ribobio (Ribobio, Guangzhou, China). The siRNAs targeting the mRNA of human Sp1 [GenBank: NM_138473.2] was denoted as siSp1-1\# (L-026959-00-0003) and siSp12\# (siG0898155658). The negative control (NC) RNA duplex for the siRNA was nonhomologous to any human genome sequences, and was indicated as siNC (D001220-01-20). CNE2 and HNE1 cells $\left(1 \times 10^{5}\right)$ were seeded on 6-well plates for $16 \mathrm{~h}$, followed by transfection with $50 \mathrm{nM}$ of the RNA duplex and $5 \mu \mathrm{L}$ of Lipofectamine RNAiMAX (Invitrogen, Grand Island, NY, USA), according to the manufacturer's instructions. After $72 \mathrm{~h}$, cells were washed with PBS and harvested for further experiments.

\section{Quantitative real-time RT-PCR}

Total RNA from NPC cell lines or tissue specimens was extracted using the TRIzol reagent (Invitrogen, Grand Island, NY, USA) according to the manufacturer's instructions. Complementary DNA (cDNA) was synthesized from 
Table 1 Clinical characteristics of 76 NPC patients

\begin{tabular}{ll}
\hline Characteristics & No. (\%) \\
\hline Gender & \\
Female & $21(27.6 \%)$ \\
Male & $55(72.4 \%)$ \\
Age (y) & \\
$\leq 45$ & $34(44.7 \%)$ \\
$>45$ & $42(55.3 \%)$ \\
Histological classification & \\
NKUC & $74(97.4 \%)$ \\
NKDC & $2(2.6 \%)$ \\
Clinical stage & \\
I & $1(1.3 \%)$ \\
II & $23(30.3 \%)$ \\
III & $27(35.5 \%)$ \\
IV & $25(32.9 \%)$ \\
T classification & \\
T1 & $10(13.2 \%)$ \\
T2 & $25(32.9 \%)$ \\
T3 & $18(23.7 \%)$ \\
T4 & $23(30.3 \%)$ \\
N classification & $33(43.4 \%)$ \\
N0 & $43(56.6 \%)$ \\
N1 &
\end{tabular}

NPC nasopharyngeal carcinoma.

NKUC non-keratinizing undifferentiated carcinoma.

NKDC non-keratinizing differentiated carcinoma.

$1 \mu \mathrm{g}$ of the total RNA using a reverse transcriptase kit (Invitrogen). The mRNA level was determined by quantitative Real-time RT-PCR (qRT-PCR) using the Power SYBR Green qPCR SuperMix-UDG (Invitrogen, Grand Island, NY, USA) and was analyzed on an ABIPrism-7500 Sequence Detector System (ABI, applied biosystems, USA). Glyceraldehyde-3-phosphate dehydrogenase (GAPDH) or $\beta$-actin was used as an internal control. The primers are listed in Table 2 . Relative expression of the indicated gene was normalized to GAPDH or $\beta$-actin expression, which yielded a $2^{-\triangle \Delta \mathrm{Ct}}$ value. All reactions were run in triplicate.

\section{Western blot}

Western blot was performed as previously described [32]. Briefly, cells were harvested and lysed in RIPA buffer containing protein inhibitor cocktail (F. HoffmannLa Roche Ltd, Basel, Switzerland). The protein concentration was determined by the BCA method (Pierce, Rockford, IL). The protein $(10 \mu \mathrm{g})$ was electrophoretically separated in 9 or 12\% SDS polyacrylamide gels, and transferred to polyvinylidene difluoride membranes (Millipore). After probing with the indicated antibodies, the signals were detected using enhanced chemiluminescence (ECL) (Amersham Pharmacia Biotech, Piscataway, NJ). The same membranes were stripped and reprobed with mouse monoclonal antibodies against GAPDH or $\alpha$-tubulin to confirm equal loading of the samples.

\section{Immunohistochemical staining (IHC)}

Immunohistochemical staining (IHC) was performed as previously described [34]. Briefly, paraffin-embedded samples were cut into $4 \mu \mathrm{m}$ sections and placed on polylysine-coated slides. Paraffin sections were baked for $2 \mathrm{~h}$ at $58^{\circ} \mathrm{C}$, de-paraffinized in xylene, rehydrated through graded ethanol, quenched for endogenous peroxidase activity in $0.3 \%$ hydrogen peroxide for $10 \mathrm{~min}$, and processed for antigen retrieval by high pressure cooking in citrate antigen retrieval solution $(\mathrm{pH}=6.0)$ for about $5 \mathrm{~min}$. Sections were incubated at $4^{\circ} \mathrm{C}$ overnight with rabbit polyclonal antibodies against $\mathrm{Sp} 1$ (Millipore, 1:3200) in a moist chamber. Immunostaining was performed using the Zymed Histostain TMPlus Kits (Zymed, South San Francisco, CA, USA), which resulted in a brown-colored precipitate at the antigen site. Subsequently, sections were counterstained with hematoxylin (Zymed Laboratories, South San Francisco, CA) and mounted in a non-aqueous mounting medium. All runs included a no primary antibody control. The immunohistochemically stained tissue sections were scored separately by two pathologists blinded to the clinical parameters. The staining intensity was scored as 0 (negative), 1 (weak), 2 (medium) or 3 (strong). Extent of staining was scored as $0(0-10 \%), 1$ (10-25\%), 2 (26-50\%) and 3 (51\%-100\%) according to the percentages of the positive staining areas in relation to the whole carcinoma area. The product of the intensity and extent score was used as the final staining score (0-9) for Sp1. Tumors having a final staining score of $<4.5$ were considered to be low and those with score of $\geq 4.5$ were considered to be high.

\section{MTT assay}

Forty-eight hours after transfection with siSp1-1\#, siSp12\# or siNC, CNE2 and HNE1 cells were plated in triplicate at 2000 cells per well in 96-well plates and maintained in RPMI containing 10\% FBS. At the indicated 
Table 2 Sequences of primers

\begin{tabular}{|c|c|c|}
\hline Name & Sense primer $\left(5^{\prime}-3^{\prime}\right)$ & Antisense primer $\left(5^{\prime}-3^{\prime}\right)$ \\
\hline SP1 & TCCAGACCATTAACCTCAGTGC & TGTATTCCATCACCACCAGCC \\
\hline$p 21$ & 5'-CCTGTCACTGTCTTGTACCCT & GCGTTGGAGTGGTAGAAATCT \\
\hline p27 & CTGCAACCGACGATTCTTCTACT & GGGCGTCTGCTCCACAGA \\
\hline BMI1 & TGGCTCGCATTCATTITCTG & TGTGGCATCAATGAAGTACCCT \\
\hline MYC & GGAGGCTATTCTGCCCATTTG & CGAGGTCATAGTTCCTGTTGGTG \\
\hline KLF4 & CACAAAGAGTTCCCATCTCAAGGC & CGGTAGTGCCTGGTCAGTTCATC \\
\hline$A B C G 2$ & CATGTACTGGCGAAGAATATTTGGT & CACGTGATTCTTCCACAAGCC \\
\hline OCT4 & GTGGAGAGCAACTCCGATG & TGCTCCAGCTTCTCCTTCTC \\
\hline GAPDH & СTCCTCCTGTTCGACAGTCAGC & CCCAATACGACCAAATCCGTT \\
\hline Actin & CGCGAGAAGATGACCCAGAT & GGGCATACCCCTCGTAGATG \\
\hline $50 \times 2$ & CGAGTGGAAACTITTGTCGGA & TGTGCAGCGCTCGCAG \\
\hline
\end{tabular}

time points, $10 \mu \mathrm{L}$ of $5 \mathrm{mg} / \mathrm{mL} \operatorname{MTT}(3-(4,5-$ dimethylthiazol-a-yl)-2, 5-diphenyl tetrazolium bromide) was added to each well, and cells were incubated for $4 \mathrm{~h}$ at $37^{\circ} \mathrm{C}$. The media was then discarded, and $200 \mu \mathrm{l}$ of DMSO was added to each well for $20 \mathrm{~min}$ at RT to dissolve the precipitates. Absorbance was measured using the Spectramax M5 (Molecular Devices, CA, USA) at a wavelength of $570 \mathrm{~nm}$.

\section{Colony formation assay}

Forty-eight hours after transfection with siSp1-1\#, siSp12\# or siNC, CNE2 and HNE1 cells were plated in triplicate at 200 cells per well in six-well plates and maintained in RPMI containing 10\% FBS for 10 days. Colonies were fixed with methanol and stained with $0.1 \%$ crystal violet in $20 \%$ methanol, and then were photographed and counted. All visible colonies were quantified.

\section{Anchorage-independent growth}

Forty-eight hours after transfection with the indicated RNA duplex, CNE2 and HNE1 cells $\left(1 \times 10^{4}\right)$ that were suspended in $0.33 \%$ top agar (in RPMI with $10 \%$ FBS) were plated onto $0.55 \%$ base agar (in RPMI with $5 \%$ FBS) in six-well plates for 14 days. The colonies with the diameter bigger than $10 \mu \mathrm{m}$ were counted.

\section{Sphere formation assay}

Forty-eight hours after transfection with the indicated RNA duplex, CNE2 cell $\left(5 \times 10^{2}\right)$ that were suspended in tumor sphere medium containing serum-free DMEM/F$12, \mathrm{~N}_{2}$ supplement, $10 \mathrm{ng} / \mathrm{mL}$ human recombinant bFGF and $10 \mathrm{ng} / \mathrm{mL}$ EGF were plated in six-well plates (ultra low attachment surface) for 7 days. Colonies were photographed at 200x magnification and were counted at $40 \times$ magnification.

\section{Statistical analysis}

All data analysis was conducted with GraphPad Prism version 4.0 (GraphPad Software, San Diego, CA, USA) and SPSS 16.0 (SPSS, Chicago, IL, USA). The results were representative of at least three independent experiments. Data were presented as the mean \pm standard error of the mean (SEM) obtained with triplicate samples. Analysis of the differences between groups was determined with the two-tailed Mann-Whitney test. A P-value of 0.05 was used as the criterion of statistical significance.

\section{Results}

High level of Sp1 correlates with tumor progression in nasopharyngeal carcinoma

To explore the significance of Sp1 in the development of nasopharyngeal carcinoma, the mRNA and protein levels of Sp1 were first examined in the normal primary nasopharyngeal epithelial cells (NPECs) and NPC cell lines. Both qRT-PCR and Western blot showed that the level of Sp1 in the four NPC cell lines (HNE1, HONE1, CNE2 and C666-1) was obviously higher than the normal primary NPECs (NPECw and NPEC01) (Figure 1). The expression and subcellular localization of Sp1 in 76 NPC tissues were then determined by immunohistochemistry. As shown in Figure 2, Sp1 was expressed predominantly in the nuclei of NPC cells of the tumor regions (T), but demonstrated weak signal in the NPEC of the nontumor regions $(\mathrm{N})$. In addition, $\mathrm{Sp} 1$ was present in some infiltrating lymphocytes of both the non-tumor and tumor regions of NPC patients. To evaluate the clinical significance of Sp1 in nasopharyngeal carcinoma, the correlation between $\mathrm{Sp} 1$ level and the clinical variations was analyzed using $\chi^{2}$ test. As shown in Table 3, the expression of $\mathrm{Sp} 1$ was significantly associated with the clinical stage $(P=0.00036), \mathrm{T}(P=0.002)$ and $\mathrm{N}(P=$ $0.034)$ classification. There was no significant correlation 


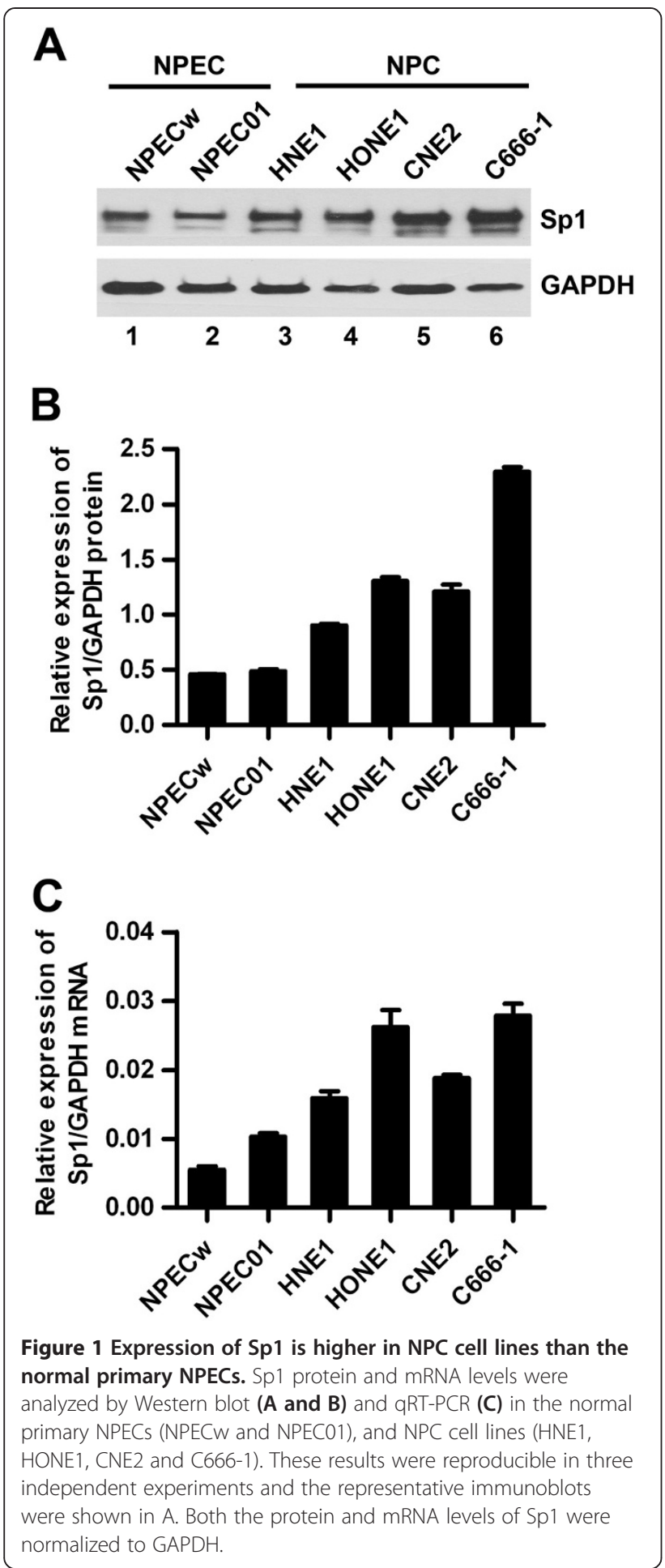

between the expression level of Sp1 and age, gender, $\mathrm{M}$ classification as well as histologic classification in NPC patients. These results suggested that the increase in intratumoral Sp1-positive NPC cells was associated with NPC progression.

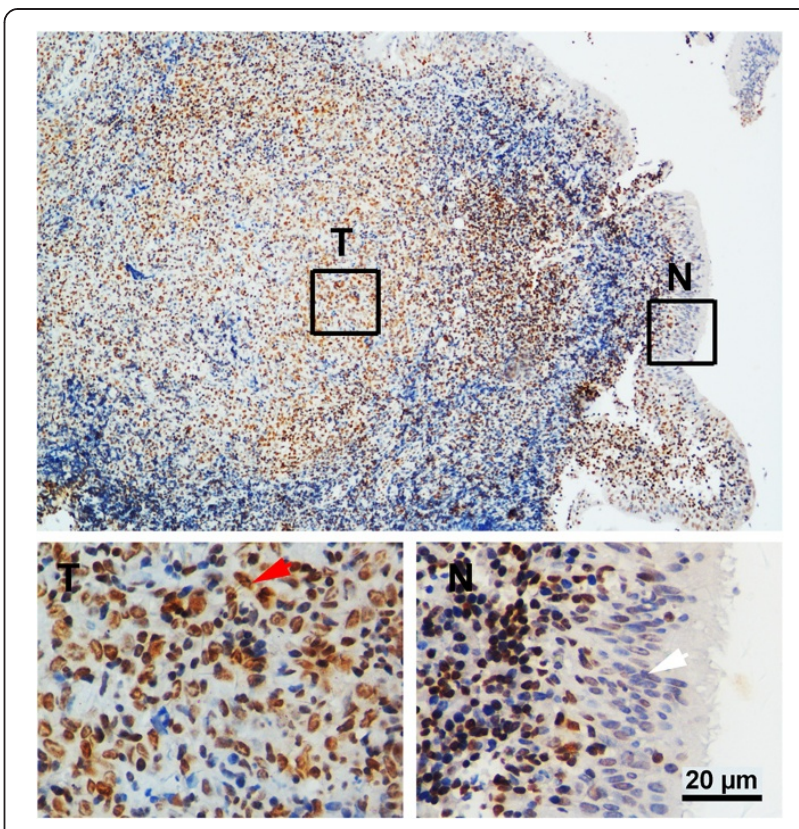

Figure 2 Expression of Sp1 in situ tumors of NPC patients. Sp1positive cells were stained brown and present in the nuclei of tumor cells and some lymphocytes. Strong positive staining for Sp1 in NPC cells of the tumor region (T) was marked as red arrow (lower left panel), while negative or weak staining for Sp1 in NPEC of the adjacent non-tumor region ( $\mathrm{N}$ ) was indicated as white arrow (lower right panel). Representative images with low (100x, upper panels) and high (400x, lower panels) magnification were shown. Scale bar $=20 \mu \mathrm{m}$.

Knockdown of Sp1 suppresses the proliferation of NPC cells To investigate the potential roles of $\mathrm{Sp} 1$ in tumorigenesis, the effect of Sp1 on the cell growth was first evaluated. CNE2 and HNE1 cells were cultured in the presence of $100 \mathrm{nM}$ mithramycin A (MITA), a FDA-approved chemotherapeutic anticancer drug that inhibits transcriptional activity of Sp1 by competitively binding to the Sp1binding sites. The cell viability was determined by MTT on the indicated times. Compared with DMSO-treated cells, the cell viability was significantly suppressed in MITA-treated CNE2 and HNE1 cells (Figure 3A).

Next, we assessed the effect of Sp1 knockdown on the cell growth of NPC cells. HNE1 and CNE2 cells were transfected with the two distinct siRNA duplexes against Sp1, and then subjected to Western blot. The level of Sp1 was nearly abolished in siSp1 transfectants (Figure 3B). Compared to the control, siSp1 transfectants displayed significantly lower proliferation, suggesting the growthpromoting role of Sp1 in NPC cells (Figure 3C).

Knockdown of Sp1 suppressed the G1/S phase transition and increased the expressions of p21 and p27

To assess whether cell cycle progression was involved in Sp1-promoted cell growth, CNE2, HNE1 and HK1 cells were transfected with the indicated RNA duplex for $48 \mathrm{~h}$, 


\begin{tabular}{|c|c|c|c|}
\hline \multirow[t]{2}{*}{ Characteristics } & \multicolumn{2}{|l|}{ Sp1 } & \multirow[t]{2}{*}{$P$} \\
\hline & Low & High & \\
\hline \multicolumn{4}{|l|}{ Age (y) } \\
\hline$\leq 45$ & $18(54.5 \%)$ & $16(37.2 \%)$ & \multirow[t]{2}{*}{0.165} \\
\hline$>45$ & $15(45.5 \%)$ & $27(62.8 \%)$ & \\
\hline \multicolumn{4}{|l|}{ Gender } \\
\hline Male & $24(72.7 \%)$ & $31(72.1 \%)$ & \multirow[t]{2}{*}{1.01} \\
\hline Female & $9(27.3 \%)$ & $12(27.9 \%)$ & \\
\hline \multicolumn{4}{|l|}{ Clinical stage } \\
\hline$|-| \mid$ & $18(54.5 \%)$ & $6(14 \%)$ & \multirow[t]{2}{*}{0.00036} \\
\hline III-IV & $15(45.5 \%)$ & 37 (86.0\%) & \\
\hline \multicolumn{4}{|l|}{ T classification } \\
\hline $\mathrm{T} 1-\mathrm{T} 2$ & $22(66.7 \%)$ & $13(30.4 \%)$ & \multirow[t]{2}{*}{0.002} \\
\hline T3-T4 & $11(33.3 \%)$ & $30(69.6 \%)$ & \\
\hline \multicolumn{4}{|l|}{$\mathrm{N}$ classification } \\
\hline NO-N1 & $25(75.8 \%)$ & $22(51.2 \%)$ & \multirow[t]{2}{*}{0.034} \\
\hline $\mathrm{N} 2-3$ & $8(24.2 \%)$ & $21(48.8 \%)$ & \\
\hline \multicolumn{4}{|l|}{ Metastases } \\
\hline No & $33(100 \%)$ & $41(95.3 \%)$ & \multirow[t]{2}{*}{0.502} \\
\hline Yes & 0 & $2(4.7 \%)$ & \\
\hline \multicolumn{4}{|c|}{ Histological classification } \\
\hline NKUC & $31(93.9 \%)$ & $43(100 \%)$ & \multirow[t]{2}{*}{0.185} \\
\hline NKDC & $2(6.1 \%)$ & 0 & \\
\hline Fisher's exact test & & & \\
\hline
\end{tabular}

followed by flow cytometry analysis for the cell cycle distribution of initially asynchronous cells. Knockdown of Sp1 showed a marked induction of G1 arrest in CNE2, HNE1 and HK1 cells, whereas had no effect on apoptosis as evaluated by sub-G1 peak (Figure 4A and B). The G1/S-phase transition has been characterized as a balance of cyclins, CDKs and Cip1 proteins. Cyclins promote $\mathrm{S}$ phase, whereas $\mathrm{p} 27$ and $\mathrm{p} 21$ maintain cells in $\mathrm{G} 1$ arrest. CDK4, p27 and p21 have been reported to regulate the G1/S-phase transition and are potentially regulated by $\mathrm{Sp} 1$ [35-37]. To study whether $\mathrm{Sp} 1$ promotes cell cycle through the expression regulation of these molecules in nasopharyngeal carcinoma, CNE2, HNE1 and HK1 cells were transfected with siSp1 and siNC for $48 \mathrm{~h}$, followed by analysis for the levels of Sp1, CDK4, p27 and p21. Either qRT-PCR or Western blot demonstrated that Sp1 knockdown obviously upregulated the levels of p27 and p21, but had no effect on the expression levels of CDK4 (Figure 4C and D), indicating Sp1 knockdown blocked the G1/S transition through induction of p27 and p21 in NPC cells.

\section{Knockdown of Sp1 suppressed clonogenicity and anchorage-independent growth}

We then analyzed the effect of Sp1 on the clonogenicity and anchorage-independent growth of NPC cells. CNE2 and HNE1 cells were transfected with the indicated RNA duplex, and then allowed to grow at very low density or grow in soft agar. The siSp1transfectants displayed obviously fewer and smaller colonies than the siNC-transfectants, as shown by a significant reduction in both the size and the number of colonies (Figure 5A and B). In addition, knockdown of Sp1 significantly suppressed the capacity of NPC cells to grow in soft agar (Figure $5 \mathrm{C}$ and $\mathrm{D}$ ). These results indicated that $\mathrm{Sp} 1$ silencing exerted a suppressive role on the colony formation and anchorageindependent growth of NPC cells.

\section{Sp1 silencing inhibited sphere formation and impaired the expressions of stem cell markers in NPC cells}

Stem cells can be expanded as sphere-like cellular aggregates in the sphere medium containing EGF and bFGF. To further determine the role of $\mathrm{Sp} 1$ silencing in the stem-cell like phenotype of NPC cells, sphere formation potential was monitored. CNE2 cells transfected with the indicated siRNA duplexes were cultivated in the sphere medium for 7 days. The sphere formation number was significantly lower in Sp1 silenced CNE2 cells (Figure 6A and B), suggesting knockdown of Sp1 may suppress the stem-cell like phenotype in CNE2 cells. Bmi1, c-Myc, KLF4, SOX2, NANOG and OCT4 are the key stem cell transcription factors (SCTFs). ABCG2, an ABC transporter member, is associated with the formation of side population and stem/progenitor features in nasopharyngeal carcinoma [38]. We therefore determined whether knockdown of Sp1-suppressed the stem-cell like phenotype was associated with changes in these molecules. Bmi1, c-Myc, KLF4 and ABCG2 were all decreased in Sp1-knockdown CNE2, HNE1 and HK1 cells (Figure 6C). In contrast, OCT4 and SOX2 was unaffected by Sp1 knockdown, indicating down-regulation of Sp1 suppressed the stem-cell like phenotype, depending on the reduced expression of Bmi1, c-Myc, KLF4, and ABCG2, but not OCT4 and SOX2 (data not shown).

Taken together, our data suggest that $\mathrm{Sp} 1$ was enriched in NPC cell lines as well as tissues and are highly correlated with the NPC progression. Down-regulation of Sp1 may induce the expression of p27 and p21, as well as the expressions of the critical SCTFs, resulting in the suppression of cell proliferation, clonogenicity, anchorageindependent growth and the stem-cell like phenotype in NPC cells. These findings demonstrated the potential use of Sp1 inhibitor in the clinical therapy of nasopharyngeal carcinoma. 

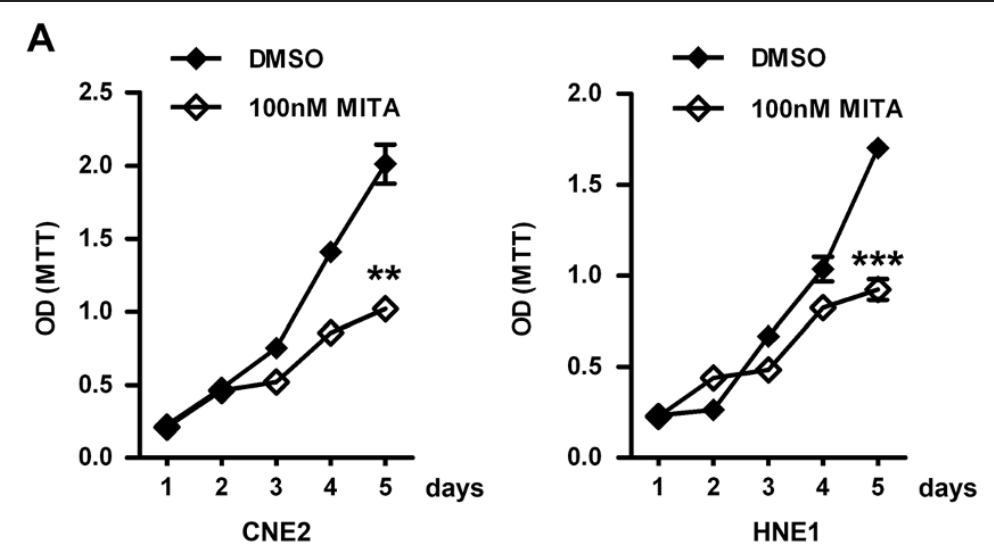

B
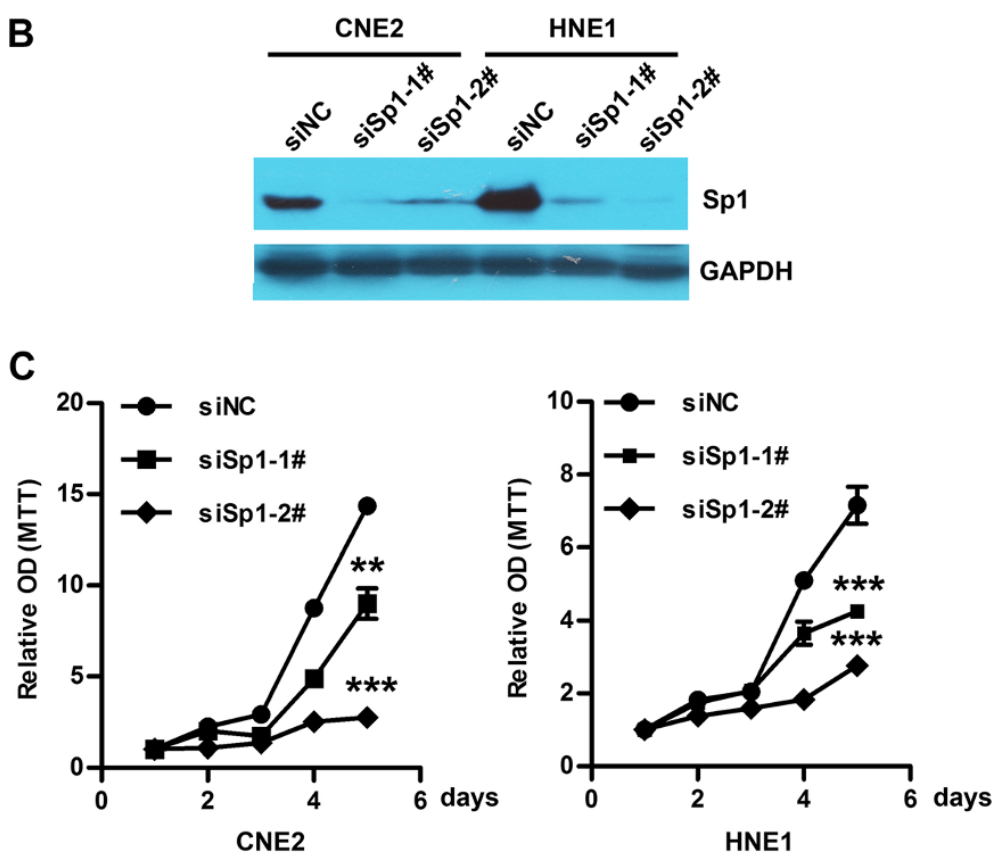

Figure 3 Both impaired Sp1 activity and expression suppressed the cell viability of NPC cells. (A) Inhibition of Sp1 activity by MITA treatment decreased the cell viability of CNE2 and HNE1 cells. Twenty-four hours after seeding in 96-well plates, CNE2 and HNE1 cells were treated with $100 \mathrm{nM}$ MITA. The cell viability was determined by MTT assay at the indicated times. ${ }^{* *} P<0.01$ and ${ }^{* * *} P<0.001$. (B) Sp1 was completely abolished in CNE2 and HNE1 cells. After transfection with siSp1-1\#, siSp1-2\# or siNC for $72 \mathrm{~h}$, cells were subjected to Western blot analysis for Sp1. GAPDH was used as an internal control. (C) Silencing of Sp1 impaired the cell viability of CNE2 and HNE1 cells. After transfection with siSp1-1\#, siSp1-2\# or siNC for 48 h, CNE2 and HNE1 cells were seeded into 96-well plates (2000/well) and incubated for the indicated times. The cell viability was determined by MTT assay at the indicated times. ${ }^{* * *} P<0.001$.

\section{Discussion}

Although Sp1 has been investigated extensively in multiple types of cancers, the level of Sp1 in nasopharyngeal carcinoma and molecular mechanisms by which Sp1 modulates the behavior of tumor cells remain elusive. In the present study, we revealed that higher level of Sp1 correlates with advanced tumor stage in nasopharyngeal carcinoma. Down-regulation of Sp1 suppressed cell growth, the G1/S phase transition, clonogenicity and anchorage-independent growth of NPC cells. Sp1 exert a specific role on the expression of genes related to cell proliferation and clonogenicity, such as p27, p21, Bmi1,
c-Myc, KLF4 and ABCG2. Taken together, these results suggest a fundamental role of $\mathrm{Sp} 1$ in the phenotypic regulation of cancer cells, and implicate the potential application of $\mathrm{Sp} 1$ in cancer therapy.

Sp1 has been extensively investigated in multiple cancers [26]. However, the significance of $\mathrm{Sp} 1$ in human head and neck cancers, such as nasopharyngeal carcinoma, has never been explored. In the present study, the pivotal roles of $\mathrm{Sp} 1$ in the cell proliferation, clonogenicity and anchorage-independent growth were confirmed in CNE2 and HNE1 or HK1 cells. G1/S phase transition is regulated by a balance of cyclins and cyclin-dependent 
B

A
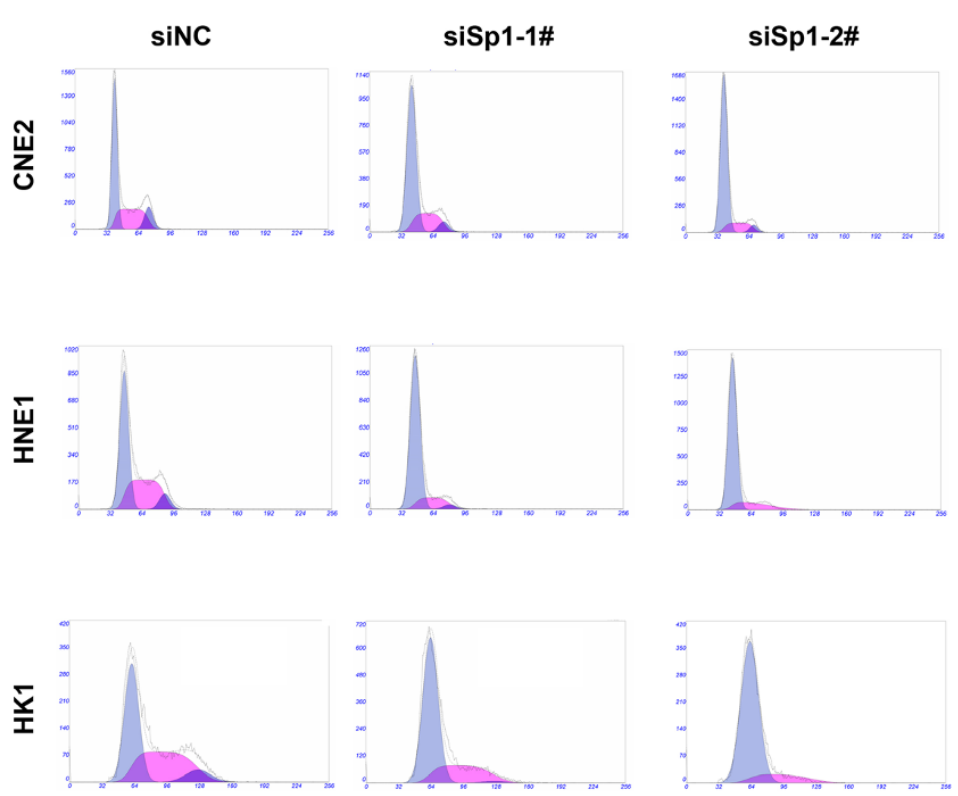

C

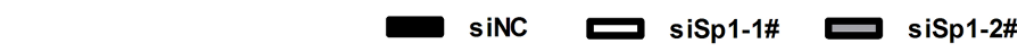

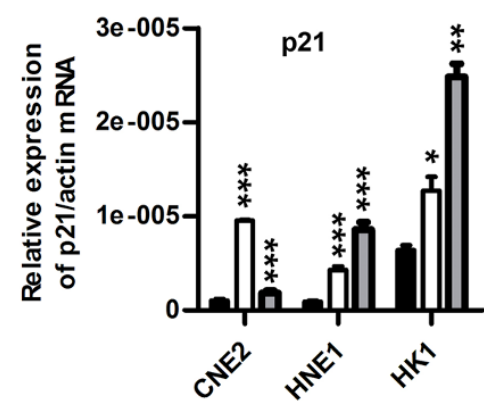

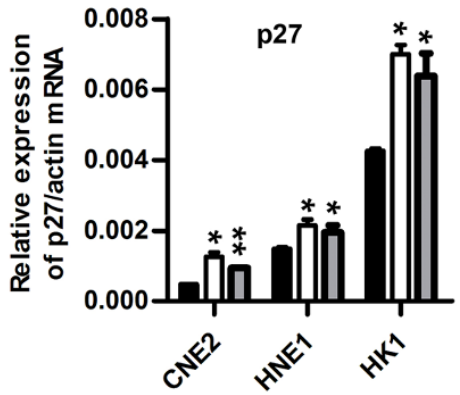

D

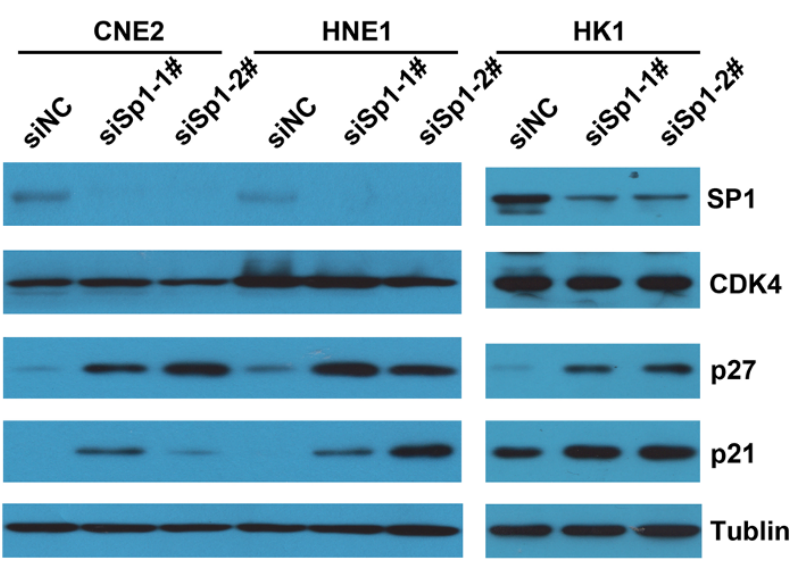

Figure 4 (See legend on next page.) 
(See figure on previous page.)

Figure 4 Knockdown of Sp1 induces G1 phase arrest and up-regulates the expressions of p21 and p27. (A and B) Knockdown of Sp1 caused accumulation of G1 population. The representative images are shown in $A$ and the percentage of cell distribution in G1/G0, S and G2/M is illustrated in B. CNE2, HNE1 and HK1 cells were plated in 6-well culture plates and transfected with siSp1-1\#, siSp1-2\# or siNC for 72 h. Cells were harvested, fixed, stained with propidium iodide and then analyzed for DNA content by flow cytometry. ${ }^{*} P<0.05,{ }^{* *} P<0.01,{ }^{* * *} P<0.001$. (C and D) Knockdown of Sp1 enhanced the expressions of p27 and p21. CNE2, HNE1 and HK1 cells transfected with siSp1-1\#, siSp1-2\# or siNC for $72 \mathrm{~h}$ were analyzed for the levels of cell cycle related genes by qRT-PCR (C) and Western blot (D). For (C), the mRNA level of the indicated gene was normalized to $\beta$-actin. ${ }^{*} P<0.05$, ${ }^{* *} P<0.01$, ${ }^{* *} P<0.001$. For (D), a-tubulin served as an internal control.

kinase inhibitors. Cyclins (e.g., cyclin D1) facilitate Sphase entry, whereas cyclin-dependent kinase inhibitors (e.g., p21 and p27) keep cells arrested in G1 phase. We found knockdown of Sp1 significantly promoted the expressions of p21 and p27 in both CNE2 and HNE1 cells, but had no obvious effect on the expressions of CDK4, suggesting suppression of $\mathrm{Sp} 1$ promoted cell arrest in G1 phase though the elevated levels of p27 and p21. Furthermore, down-regulation of Sp1 may suppress the acquisition of cancer stem cell phenotypes through the reduced expressions of SCTFs, including Bmi1, c-Myc and KLF4. Taken together, Sp1 promotes proliferation, clonogenicity and anchorage-independent growth of NPC cells.

In addition to being as an oncogene, $\mathrm{Sp} 1$ can also act as a tumor suppressor in various types of cancer. Chuang et al. reported that $\mathrm{Sp} 1$ overexpression suppressed the cell growth and increased the sub-G1 fraction, caspase-3 cleavage, and annexin-V signal in HeLa and A549 cells. When cells entered the mitotic stage, Sp1 overexpression could induce p53-dependent apoptosis through affecting mitotic chromatin packaging. Moreover, Hsu reported that the proportion of low $\mathrm{Sp} 1$ expression in patients with stage IV lung adenocarcinoma was higher than that in patients with stages I and II of lung adenocarcinoma. Sp1 negatively correlated with poor prognosis. Sp1 level accumulated strongly in early stage and was required for lung tumor growth, but it was declined in late stage and suppressed metastasis through inducing E-cadherin expression. Therefore, the role of $\mathrm{Sp} 1$ in tumor development is paradox and variable, largely depending on the cellular context.

We previously reported that $\mathrm{Sp} 1$ activates the transcription of Bmil and CENPH in nasopharyngeal carcinoma [32,33]. Both Bmi1 and CENPH are oncogenes which are elevated in various malignancies originating in the breast, esophagus and nasopharynx [39-41]. Higher levels of Bmil and CENPH are correlated with an advanced stage and/or unfavorable prognosis. Bmil, a member of the polycomb group, promotes tumor progression by inhibiting the transcription of tumor suppressors, such as p53 [42], p21 [43], INK4a and p19 ${ }^{\text {Arf }}$ [44]. CENPH, a basic component of the constitutive centromere-associated network, induces continuous chromosome instability during
A

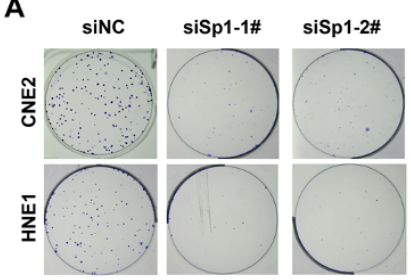

B

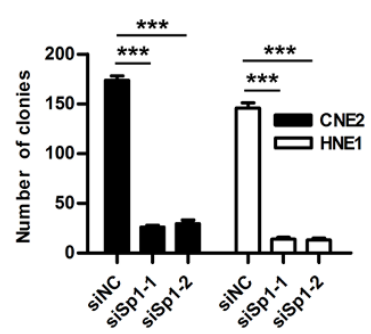

C

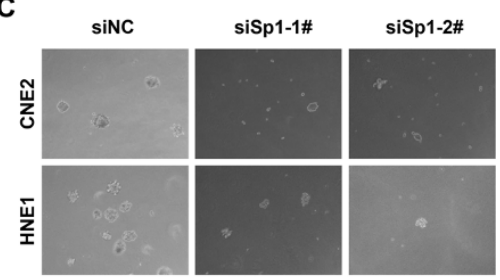

D

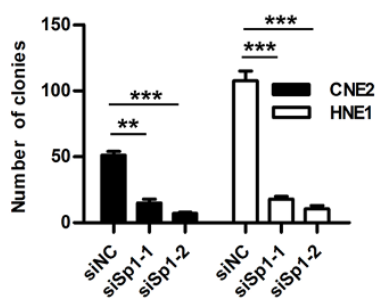

Figure 5 Knockdown of Sp1 suppressed the clonogenicity and anchorage-independent growth of NPC cells. CNE2 and HNE1 cells transfected with either siSp1-1\#, siSp1-2\# or siNC were grow at low density for 10 days (A and B) or were plated onto 0.55\% base agar (in RPMI with 5\% FBS) in six-well plates for 14 days. For (A and B) Colonies were fixed with methanol and stained with $0.1 \%$ crystal violet in $20 \%$ methanol, and then were photographed and counted. All visible colonies were quantified. For ( $C$ and $\mathbf{D})$, the colonies with the diameter bigger than $100 \mu \mathrm{m}$ were counted. ${ }^{* *} P<0.01,{ }^{* * *} P<0.001$. 


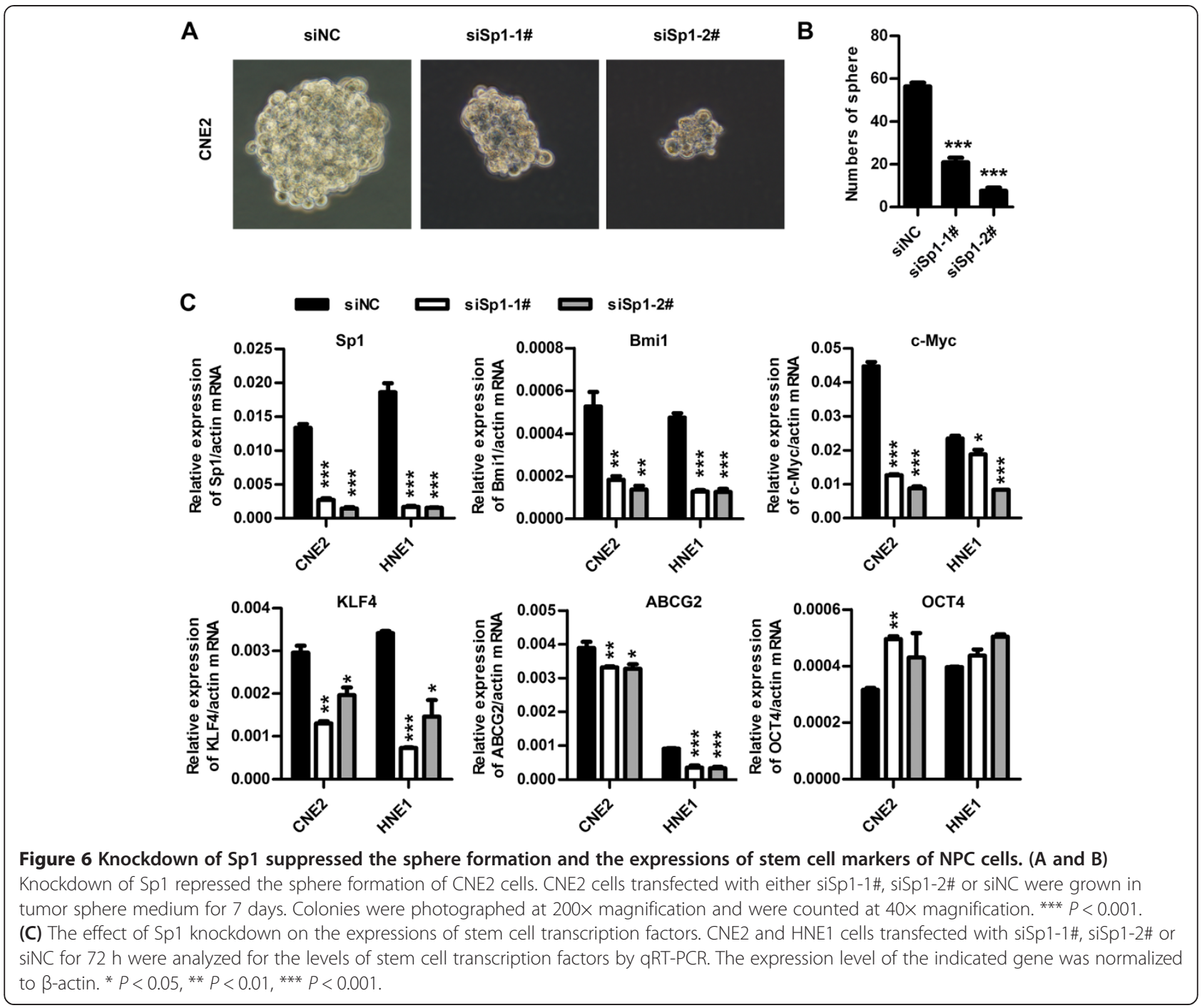

mitosis, which is found in the earliest stages of tumorigenesis [39]. Therefore, the cancer-promoting role of Sp1 may also be mediated by transcriptional activation of its downstream genes, such as Bmil and CENPH.

MITA, an aureolic acid-type polyketide isolated from streptomyces, specifically inhibits binding of Sp1 to GCrich DNA and thus suppressed the Sp1-targeted genes mediating proliferation, angiogenesis, invasion and metastasis [45]. It has been used in the treatment of various malignancies, including testicular carcinoma [46], osteolytic myelomatosis [47], pancreatic cancer [48]. However, the role of MITA in NPC has never been explored. In this study, MITA was found to significantly repress the cell viability of both CNE2 and HNE1 cells, indicating Sp1 may be the potential target in the clinical therapy of nasopharyngeal carcinoma.

In summary, we investigated the expression level and potential role of $\mathrm{Sp} 1$ in nasopharyngeal carcinoma and its underlying mechanisms. Our data revealed that higher level of Sp1 may play important role in the development of nasopharyngeal carcinoma and highlighted the potential use of $\mathrm{Sp} 1$ inhibitor in the clinical therapy of NPC.

\section{Conclusions}

In the present study, we found the level of Sp1 was elevated in cancerous than in normal primary NPECs, and was higher in NPC tissues with advanced clinical stage than that with early clinical stage. Either inhibition of Sp1 activity by mithramycin A, the FDA-approved chemotherapeutic anticancer drug or knockdown of Sp1 by siRNA duplex suppressed the growth of NPC cells. Furthermore, we demonstrated that silencing of Sp1 inhibited cell proliferation, clonogenicity, anchorage-independent growth and the stem-cell like phenotype of NPC cells through inducing the expression of p27 and p21, and through impairing the expressions of SCTFs, including Bmi1, c-Myc, KLF4, NANOG and OCT4 in NPC cells. 
These findings highlight the significance of Sp1 downregulation in suppressing cell proliferation, clonogenicity, anchorage-independent growth and the stem-cell like phenotype, implicating Sp1 as an attractive candidate for NPC therapy.

\section{Abbreviations \\ Bmi1: B-lymphoma mouse Moloney leukemia virus insertion region 1; \\ CENPH: Centromere protein H; IHC: Immunohistochemistry staining: \\ MITA: Mithramycin A; NPC: Nasopharyngeal carcinoma; \\ NPEC: Nasopharyngeal epithelial cells; NKUC: Non-keratinizing \\ undifferentiated carcinoma; NKDC: Non-keratinizing differentiated carcinoma; qRT-PCR: Quantitative Real-time RT-PCR; SCTFs: Stem cell transcription factors. \\ Competing interests \\ The authors declare no competing interests. \\ Authors' contributions \\ JPZ participated in the design of the study, performed the statistical analysis, and drafted the manuscript. HZ performed real-time PCR experiments and Western blot. HBW carried out the key experiments, performed statistical analysis, prepared figures and tables, and drafted the manuscript. YXL carried out immunohistochemistry staining. GHL participated in the cell culture. SX performed flow cytometry analysis. MZL provided important comments in the cell culture. MSZ conceived of the study, and participated in its design and coordination and helped to draft the manuscript. All authors read and approved the final manuscript.}

\section{Acknowledgements}

This work was supported by the National Basic Research Program of China (Grant No. 2012CB967003), China National Funds for Distinguished Young Scientists (Grant No. 81025014), National Natural Science Foundation of China (Grant No. 81202137), Sun Yat-Sen University Young Talent Teachers Plan (12ykpy51).

\section{Author details}

'State Key Laboratory of Oncology in South China, Sun Yat-sen University Cancer Center, 651 Dongfeng Road East, Guangzhou 510060, China. ${ }^{2}$ Department of Experimental Research, Sun Yat-sen University Cancer Center, Guangzhou, China. ${ }^{3}$ Department of Oncology, the Second Affiliated Hospital of Guangzhou medical college, Guangzhou, China.

Received: 16 March 2014 Accepted: 31 July 2014

Published: 7 August 2014

\section{References}

1. Tao Q, Chan AT: Nasopharyngeal carcinoma: molecular pathogenesis and therapeutic developments. Expert Rev Mol Med 2007, 9:1-24.

2. Lo KW, To KF, Huang DP: Focus on nasopharyngeal carcinoma. Cancer Cell 2004, 5:423-428

3. Wei WI, Sham JS: Nasopharyngeal carcinoma. Lancet 2005, 365:2041-2054.

4. Feng BJ, Huang W, Shugart YY, Lee MK, Zhang F, Xia JC, Wang HY, Huang TB, Jian SW, Huang P, Feng QS, Huang LX, Yu XJ, Li D, Chen LZ, Jia WH, Fang Y, Huang HM, Zhu JL, Liu XM, Zhao Y, Liu WQ, Deng MQ, Hu WH, Wu SX, Mo HY, Hong MF, King MC, Chen Z, Zeng YX: Genome-wide scan for familial nasopharyngeal carcinoma reveals evidence of linkage to chromosome 4. Nat Genet 2002, 31:395-399.

5. Lo YM, Chan LY, Chan AT, Leung SF, Lo KW, Zhang J, Lee JC, Hjelm NM, Johnson PJ, Huang DP: Quantitative and temporal correlation between circulating cell-free epstein-barr virus DNA and tumor recurrence in nasopharyngeal carcinoma. Cancer Res 1999, 59:5452-5455.

6. Chien YC, Chen JY, Liu MY, Yang HI, Hsu MM, Chen CJ, Yang CS: Serologic markers of epstein-barr virus infection and nasopharyngeal carcinoma in Taiwanese men. N Engl J Med 2001, 345:1877-1882.

7. Lin JC, Wang WY, Chen KY, Wei YH, Liang WM, Jan JS, Jiang RS: Quantification of plasma epstein-barr virus DNA in patients with advanced nasopharyngeal carcinoma. N Engl J Med 2004, 350:2461-2470.

8. Xu FH, Xiong D, Xu YF, Cao SM, Xue WQ, Qin HD, Liu WS, Cao JY, Zhang Y, Feng QS, Chen LZ, Li MZ, Liu ZW, Liu Q, Hong MH, Shugart YY, Zeng YX, Zeng MS, Jia WH: An epidemiological and molecular study of the relationship between smoking, risk of nasopharyngeal carcinoma, and Epstein-Barr virus activation. J Natl Cancer Inst 2012, 104:1396-1410.

9. Gallicchio L, Matanoski G, Tao XG, Chen L, Lam TK, Boyd K, Robinson KA, Balick L, Mickelson S, Caulfield LE, Herman JG, Guallar E, Alberg AJ: Adulthood consumption of preserved and nonpreserved vegetables and the risk of nasopharyngeal carcinoma: a systematic review. Int I Cancer 2006, 119:1125-1135.

10. Chan AT, Ma BB, Lo YM, Leung SF, Kwan WH, Hui EP, Mok TS, Kam M, Chan LS, Chiu SK, Yu KH, Cheung KY, Lai K, Lai M, Mo F, Yeo W, King A, Johnson PJ, Teo PM, Zee B: Phase II study of neoadjuvant carboplatin and paclitaxel followed by radiotherapy and concurrent cisplatin in patients with locoregionally advanced nasopharyngeal carcinoma: therapeutic monitoring with plasma Epstein-Barr virus DNA. J Clin Oncol 2004, 22:3053-3060.

11. Niu X, Hu C, Kong L: Experience with combination of cetuximab plus intensity-modulated radiotherapy with or without chemotherapy for locoregionally advanced nasopharyngeal carcinoma. J Cancer Res Clin Oncol 2013, 139:1063-1071.

12. Ma BB, Kam MK, Leung SF, Hui EP, King AD, Chan SL, Mo F, Loong H, Yu BK, Ahuja A, Chan AT: A phase II study of concurrent cetuximab-cisplatin and intensity-modulated radiotherapy in locoregionally advanced nasopharyngeal carcinoma. Ann Oncol 2012, 23:1287-1292.

13. Hirose T, Horvitz HR: An Sp1 transcription factor coordinates caspasedependent and -independent apoptotic pathways. Nature 2013, 500:354-358.

14. Karlseder J, Rotheneder H, Wintersberger E: Interaction of Sp1 with the growth- and cell cycle-regulated transcription factor E2F. Mol Cell Biol 1996, 16:1659-1667.

15. Black AR, Jensen D, Lin SY, Azizkhan JC: Growth/cell cycle regulation of Sp1 phosphorylation. J Biol Chem 1999, 274:1207-1215.

16. Khan S, Abdelrahim M, Samudio I, Safe S: Estrogen receptor/Sp1 complexes are required for induction of cad gene expression by 17betaestradiol in breast cancer cells. Endocrinology 2003, 144:2325-2335.

17. Duttenhoefer F, Biswas SK, Igwe JC, Sauerbier S, Bierhaus A: Sp1-dependent regulation of PPARalpha in bone metabolism. Int J Oral Maxillofac Implants 2014, 29:e107-e116.

18. Chen Y, Huang Y, Huang Y, Xia X, Zhang J, Zhou Y, Tan Y, He S, Qiang F, Li A, Re OD, Li G, Zhou J: JWA suppresses tumor angiogenesis via Sp1activated matrix metalloproteinase-2 and its prognostic significance in human gastric cancer. Carcinogenesis 2014, 35:442-451.

19. Wei D, Wang L, He Y, Xiong HQ, Abbruzzese JL, Xie K: Celecoxib inhibits vascular endothelial growth factor expression in and reduces angiogenesis and metastasis of human pancreatic cancer via suppression of Sp1 transcription factor activity. Cancer Res 2004, 64:2030-2038.

20. Hsu TI, Wang MC, Chen SY, Yeh YM, Su WC, Chang WC, Hung JJ: Sp1 expression regulates lung tumor progression. Oncogene 2012, 31:3973-3988.

21. Jungert $K$, Buck A, von Wichert G, Adler G, Konig A, Buchholz M, Gress TM, Ellenrieder $\mathrm{V}: \mathrm{Sp} 1$ is required for transforming growth factor-betainduced mesenchymal transition and migration in pancreatic cancer cells. Cancer Res 2007, 67:1563-1570.

22. Abdelrahim M, Samudio I, Smith R 3rd, Burghardt R, Safe S: Small inhibitory RNA duplexes for Sp1 mRNA block basal and estrogen-induced gene expression and cell cycle progression in MCF-7 breast cancer cells. J Biol Chem 2002, 277:28815-28822.

23. Chiefari E, Brunetti A, Arturi F, Bidart JM, Russo D, Schlumberger M, Filetti S: Increased expression of AP2 and Sp1 transcription factors in human thyroid tumors: a role in NIS expression regulation? BMC Cancer 2002, 2:35.

24. Jiang NY, Woda BA, Banner BF, Whalen GF, Dresser KA, Lu D: Sp1, a new biomarker that identifies a subset of aggressive pancreatic ductal adenocarcinoma. Cancer Epidemiol Biomarkers Prev 2008, 17:1648-1652.

25. Wang L, Wei D, Huang S, Peng Z, Le X, Wu TT, Yao J, Ajani J, Xie K: Transcription factor Sp1 expression is a significant predictor of survival in human gastric cancer. Clin Cancer Res 2003, 9:6371-6380.

26. Li L, Davie JR: The role of Sp1 and Sp3 in normal and cancer cell biology. Ann Anat 2010, 192:275-283.

27. Majello B, De Luca P, Suske G, Lania L: Differential transcriptional regulation of c-myc promoter through the same DNA binding sites targeted by Sp1-like proteins. Oncogene 1995, 10:1841-1848.

28. Marampon F, Casimiro MC, Fu M, Powell MJ, Popov VM, Lindsay J, Zani BM, Ciccarelli C, Watanabe G, Lee RJ, Pestell RG: Nerve growth factor regulation of cyclin D1 in PC12 cells through a p21RAS extracellular signal- 
regulated kinase pathway requires cooperative interactions between Sp1 and nuclear factor-kappaB. Mol Biol Cell 2008, 19:2566-2578.

29. Pore N, Liu S, Shu HK, Li B, Haas-Kogan D, Stokoe D, Milanini-Mongiat J, Pages G, O'Rourke DM, Bernhard E, Maity A: Sp1 is involved in Aktmediated induction of VEGF expression through an HIF-1-independent mechanism. Mol Biol Cell 2004, 15:4841-4853.

30. Chen YJ, Chang WM, Liu YW, Lee CY, Jang YH, Kuo CD, Liao HF: A small-molecule metastasis inhibitor, norcantharidin, downregulates matrix metalloproteinase- 9 expression by inhibiting Sp1 transcriptional activity in colorectal cancer cells. Chem Biol Interact 2009, 181:440-446.

31. Chuang JY, Wu CH, Lai MD, Chang WC, Hung JJ: Overexpression of Sp1 leads to p53-dependent apoptosis in cancer cells. Int J Cancer 2009, 125:2066-2076.

32. Wang HB, Liu GH, Zhang $H$, Xing $S$, Hu LI, Zhao WF, Xie B, Li MZ, Zeng BH, Li Y, Zeng MS: Sp1 and c-Myc regulate transcription of BMI1 in nasopharyngeal carcinoma. FEBS J 2013, 280:2929-2944

33. Zhao WF, Wang HB, Xie B, Hu LJ, Xu LH, Kuang BH, Li MZ, Zhang X: Sp1 and $\mathrm{Sp} 3$ are involved in the full transcriptional activity of centromere protein $\mathrm{H}$ in human nasopharyngeal carcinoma cells. FEBS J 2012, 279:2714-2726.

34. Song LB, Zeng MS, Liao WT, Zhang L, Mo HY, Liu WL, Shao JY, Wu QL, Li MZ, Xia YF, Fu LW, Huang WL, Dimri GP, Band V, Zeng YX: Bmi-1 is a novel molecular marker of nasopharyngeal carcinoma progression and immortalizes primary human nasopharyngeal epithelial cells. Cancer Res 2006, 66:6225-6232.

35. Willoughby JA Sr, Sundar SN, Cheung M, Tin AS, Modiano J, Firestone GL: Artemisinin blocks prostate cancer growth and cell cycle progression by disrupting Sp1 interactions with the cyclin-dependent kinase-4 (CDK4) promoter and inhibiting CDK4 gene expression. J Biol Chem 2009, 284:2203-2213.

36. Grinstein $E$, Jundt F, Weinert I, Wernet P, Royer HD: Sp1 as G1 cell cycle phase specific transcription factor in epithelial cells. Oncogene 2002, 21:1485-1492.

37. Kavurma MM, Khachigian LM: Sp1 inhibits proliferation and induces apoptosis in vascular smooth muscle cells by repressing p21WAF1/Cip1 transcription and cyclin D1-Cdk4-p21WAF1/Cip1 complex formation. J Biol Chem 2003, 278:32537-32543.

38. Kong QL, Hu L, Cao JY, Huang YJ, Xu LH, Liang Y, Xiong D, Guan S, Guo BH, Mai HQ, Chen QY, Zhang X, Li MZ, Shao JY, Qian CN, Xia YF, Song LB, Zeng YX, Zeng MS: Epstein-Barr virus-encoded LMP2A induces an epithelial-mesenchymal transition and increases the number of side population stem-like cancer cells in nasopharyngeal carcinoma. PLOS Pathog 2010, 6:e1000940.

39. Liao WT, Song LB, Zhang HZ, Zhang X, Zhang L, Liu WL, Feng Y, Guo BH, Mai HQ, Cao SM, Li MZ, Qin HD, Zeng YX, Zeng MS: Centromere protein H is a novel prognostic marker for nasopharyngeal carcinoma progression and overall patient survival. Clin Cancer Res 2007, 13:508-514.

40. Guo XZ, Zhang G, Wang JY, Liu WL, Wang F, Dong JQ, Xu LH, Cao JY, Song $L B$, Zeng MS: Prognostic relevance of centromere protein $\mathrm{H}$ expression in esophageal carcinoma. BMC Cancer 2008, 8:233.

41. Liao WT, Feng Y, Li ML, Liu GL, Li MZ, Zeng MS, Song LB: Overexpression of centromere protein $\mathrm{H}$ is significantly associated with breast cancer progression and overall patient survival. Chin J Cancer 2011, 30:627-637.

42. Calao M, Sekyere EO, Cui HJ, Cheung BB, Thomas WD, Keating J, Chen JB, Raif A, Jankowski K, Davies NP, Bekkum MV, Chen B, Tan O, Ellis T, Norris MD, Haber M, Kim ES, Shohet JM, Trahair TN, Liu T, Wainwright BJ, Ding HF, Marshall GM: Direct effects of Bmi1 on p53 protein stability inactivates oncoprotein stress responses in embryonal cancer precursor cells at tumor initiation. Oncogene 2013, 32:3616-3626.

43. Fasano CA, Dimos JT, Ivanova NB, Lowry N, Lemischka IR, Temple S: shRNA knockdown of Bmi-1 reveals a critical role for p21-Rb pathway in NSC self-renewal during development. Cell Stem Cell 2007, 1:87-99.

44. Bruggeman SW, Hulsman D, Tanger E, Buckle T, Blom M, Zevenhoven J, van Tellingen $\mathrm{O}$, van Lohuizen $\mathrm{M}$ : Bmi1 controls tumor development in an Ink4a/Arf-independent manner in a mouse model for glioma. Cancer Cell 2007, 12:328-341.

45. Gao Y, Jia Z, Kong X, Li Q, Chang DZ, Wei D, Le X, Suyun H, Huang S, Wang $L$, Xie K: Combining betulinic acid and mithramycin a effectively suppresses pancreatic cancer by inhibiting proliferation, invasion, and angiogenesis. Cancer Res 2011, 71:5182-5193.
46. Kennedy BJ, Torkelson JL: Long-term follow-up of stage III testicular carcinoma treated with mithramycin (plicamycin). Med Pediatr Oncol 1995, 24:327-328.

47. Stamp TC, Child JA, Walker PG: Treatment of osteolytic myelomatosis with mithramycin. Lancet 1975, 1:719-722.

48. Yuan P, Wang L, Wei D, Zhang J, Jia Z, Li Q, Le X, Wang H, Yao J, Xie K: Therapeutic inhibition of $\mathrm{Sp} 1$ expression in growing tumors by mithramycin a correlates directly with potent antiangiogenic effects on human pancreatic cancer. Cancer 2007, 110:2682-2690.

doi:10.1186/s12967-014-0222-1

Cite this article as: Zhang et al: Down-regulation of Sp1 suppresses cell proliferation, clonogenicity and the expressions of stem cell markers in nasopharyngeal carcinoma. Journal of Translational Medicine 2014 12:222.

\section{Submit your next manuscript to BioMed Central and take full advantage of:}

- Convenient online submission

- Thorough peer review

- No space constraints or color figure charges

- Immediate publication on acceptance

- Inclusion in PubMed, CAS, Scopus and Google Scholar

- Research which is freely available for redistribution 